\title{
Evaluation of contribution of salinity, irradiance, and nutrient deficiency into the yield of cells and $\beta$-carotene accumulation in the culture of Dunaliella salina (Chlorophyta)
}

\author{
VICTORIA PAVLIVNA KOMARISTAYA \\ KATERYNA MYKOLAIVNA BILOUSOVA \\ OLEKSANDR MYKOLAIOVYCH RUDAS
}

KomaristayA V.P., BILOUSOVA K.M., RudAS O.M. (2018). Evaluation of contribution of salinity, irradiance, and nutrient deficiency into the yield of cells and $\boldsymbol{\beta}$-carotene accumulation in the culture of Dunaliella salina (Chlorophyta). Chornomors' $k$. bot. $z$., 14 (1): 43-55. doi: 10.14255/2308-9628/18.141/4

The purpose of the study was to evaluate the contribution of salinity, irradiance, nitrate and phosphate, and their interactions into the yield of cell number and $\beta$-carotene accumulation in Dunaliella salina. To avoid confounding of the effects of factors-conditions by the depletion of factors-resources, the alga was grown in fed-batch culture. In the level ranges of the experimental factors (irradiance 2-8 klx, salinity 1-4 M NaCl, $\mathrm{KNO}_{3} 0-80 \mathrm{mg} \mathrm{L}-1$, $\mathrm{K}_{2} \mathrm{HPO}_{4}$ 0-10 mg L-1), nitrate and phosphate influenced the productivity of culture by cell number and $\beta$-carotene accumulation more strongly than salinity and irradiance. Effects of salinity and irradiance depended on nutrients and their pre-supply to the inoculum. Total effect size $\eta^{2}$ of nutrients on cell yield comprised 0,59 for non-starved and 0,43 for starved inoculum, whereas total effect size of factors-conditions $-0,10$ and 0,12 correspondingly. As to cellular $\beta$-carotene content, total effect size of nutrients on the cells grown from nonstarved and starved inoculum was 0,71 and 0,58 , and of factors conditions $-0,8$ and 0,5 correspondingly. Remained variances of cell yield and $\beta$-carotene content were attributed to the interactions of salinity and irradiance with the nutrients. The combination of high values of salinity and irradiance exerted its own, unconfounded by depletion of nutrients, but lower influence on $\beta$-carotene accumulation. The highest $\beta$-carotene content of $53 \mathrm{pg}$ per cell was observed in the culture grown from the starved inoculum at the deficiency of phosphorus. Combination of high salinity and irradiance values yielded $17 \mathrm{pg}$ of $\beta$-carotene per cell compared to about 5 pg under the optimal culture conditions. Controll nutrient supply would be the most powerful tool for biosynthesis control in D. salina culture.

Key words: nitrate, phosphate, microalga, cultivation methodology

КОМАРИСТА В.П., БІЛОУСОВА К.М., РУДАСЬ О.М. (2018). Кількісне визначення внеску солоності, освітленості та дефіциту біогенів у вихід клітин і накопичення $\boldsymbol{\beta}$-каротину в культурі Dunaliella salina (Chlorophyta). Чорноморськ. бот. ж., 14 (1): 43-55. doi: 10.14255/2308-9628/18.141/4

Метою дослідження було кількісне визначення внеску солоності, освітленості, нітрату, фосфату та їхної взаємодії до врожаю Dunaliella salina за кількістю клітин та накопиченням $\beta$-каротину. Щоб запобігти змішенню ефектів факторів-умов 3 вичерпанням факторів-ресурсів, водорість вирощували в періодичній культурі 3 підживленням. В дослідженому діапазоні факторів (освітленість 2-8 клк, солоність 1-4 M NaCl, $\mathrm{KNO}_{3}$ 0-80 мг/л, $\mathrm{K}_{2} \mathrm{HPO}_{4}$ 0-10 мг/л), нітрат і фосфат сильніше впливали на продуктивність культури за кількістю клітин та накопиченням $\beta$-каротину, ніж солоність та освітленість. Вплив солоності та освітленості залежав від біогенів та

(C) Komaristaya V.P., Bilousova K.M., Rudas O.M.

Чорноморськ. бот. ж., 14 (1): 43-55. 
попередньої забезпеченості інокуляту ними. Загальна сила впливу $\eta^{2}$ біогенів на врожай клітин складала 0,59 для неголодуючого за біогенами інокуляту та 0,43 для голодуючого інокуляту, тоді як загальна сила впливу факторів-умов - 0,10 та 0,12 відповідно. Щодо вмісту $\beta$-каротину в клітинах, загальна сила впливу біогенів на клітини, вирощені з неголодуючого та голодуючого інокулятів дорівнювали 0,71 та 0,58, і факторів умов - 0,8 та 0,5 відповідно. Залишкова дисперсія врожаю клітин i вмісту $\beta$-каротину в клітинах була віднесена до взаємодії солоності та освітленості 3 біогенами. Поєднання високих значень солоності та освітленості мало свій власний, не змішаний з вичерпанням поживних елементів, але менший індукуючий вплив на накопичення $\beta$-каротину. Найбільший вміст $\beta$-каротину 53 пг на клітину спостерігався в культурі, вирощеній з голодуючого інокуляту за дефіциту фосфору. Поєднання високих значень солоності та освітленості давало 17 пг $\beta$-каротину на клітину порівняно з близько 5 пг за оптимальних умов культивування. Дозування біогенів має бути найпотужнішим інструментом управління біосинтезом в культурі D. salina.

Ключові слова: нітрат, фосфат, мікроводосрості, методологія культивування

КОМАРИСТАЯ В.П., БЕЛОУСОВА Е.Н., РУДАСЬ А.Н. (2018). Количественное определение вклада солености, освещенности и дефицита биогенов в выход клеток и накопление $\beta$-каротина в культуре Dunaliella salina Teodor. (Chlorophyta). Черноморск. бот. ж., 14 (1): 43-55. doi: 10.14255/2308-9628/18.141/4

Целью исследования было количественное определение вклада солености, освещенности, нитрата, фосфата и их взаимодействия в урожай Dunaliella salina по количеству клеток и накоплению $\beta$-каротина. Чтобы предотвратить смешение эффектов факторов-условий с исчерпанием факторов-ресурсов, водоросль выращивали в периодической культуре с подпиткой. В исследованном диапазоне факторов (освещенность 2-8 клк, соленость 1-4 M NaCl, $\mathrm{KNO}_{3}$ 0-80 мг/л, $\mathrm{K}_{2} \mathrm{HPO}_{4} \mathrm{O}_{-}$ 10 мг/л), нитрат и фосфат сильнее влияли на продуктивность культуры по количеству клеток и накоплению $\beta$-каротина, чем соленость и освещенность. Влияние солености о освещенности зависело от биогенов и предшествовашей обеспеченности инокулята ними. Суммарная сила действия $\eta^{2}$ биогенов на урожай клеток составляла 0,59 для неголодающего по биогенам инокулята и 0,43 для голодающего инокулята, тогда как суммарная сила действия факторов-условий - 0,10 и 0,12 соответственно. По содержанию $\beta$-каротина в клетках, суммарная сила действия биогенов на клетки, выращенные из неголодающего и голодающего инокулятов составила 0,71 и 0,58 , а факторов условий $-0,8$ и 0,5 соответственно. Остаточная дисперсия урожая клеток и содержания $\beta$-каротина в клетках была отнесена к взаимодействию солености и освещенности с биогенами. Сочетание высоких значений солености и освещенности имело свое собственное, не смешанное с исчерпанием питательных элементов, но меньшее индуцирующее влияние на накопление $\beta$-каротина. Наибольшее содержание $\beta$-каротина 53 пг на клетку наблюдалось в культуре, выращенной из голодающего инокулята при дефиците фосфора. Сочетание высоких значений солености и освещенности давало 17 пг $\beta$-каротина на клетку по сравнению с около 5 пг при оптимальных условиях культивирования. Дозирование биогенов должно быть самым мощным инструментом управления биосинтезом в культуре D. salina.

Ключевые слова: нитрат, фосфат, микроводоросли, методология культивирования

Microalga Dunaliella salina Teodor. lives in hyperhaline waters (continental salt lakes, coastal lagoons, solar saltern ponds). Its massive development and intracellular $\beta$ carotene accumulation often causes red "bloom" of these habitats [OREN, 2014].

The microalga is of great practical importance as a source of $\beta$-carotene. Food industry uses the biomass as a functional ingredient (provitamin A, antioxidant), and extracted mixed carotenoids (mainly $\beta$-carotene) - as the food colorant E 160 a (i) [EFSA..., 2012]. World market demand for these products is steadily growing [MÄRZ, 2008].

Open pond culture remains the only cost-effective way to manufacture algal biomass [BEN-AMOTZ, 2009]. Currently D. salina is manufactured mostly in Australia - extensively, in 
natural lagoons separated into large ponds (100-250 ha), under wind mixing [SCHLIPALIUS, 1991; CURTAIN, 2000], and in Israel - intensively, in open artificial raceways (up to $3000 \mathrm{~m}^{2}$ ), under forced mixing and $\mathrm{CO}_{2}$ supply in relatively controlled environment [BEN-AMOTZ, 2004; DEL CAMPO et al., 2007]. The larger the pond area, the lower the control [BEN-AMOTZ, AVRON, 1990; DEL CAMPO et al., 2007].

In Mediterranean and Black Sea basins many solar salterns have persisted, partially or fully abandoned, that could be restored for cultivating D. salina [LÓPEZ et al., 2010; RoDRIGUES et al., 2011; KomARISTAYA et al., 2014]. The further to the North and the shorter warm and sunny season, the more culture feasibility dependent on optimization and control of culture conditions [BOROWITZKA, 1999].

Theory and practice proved the two step technology of $D$. salina cultivation, because of mismatch between the optima for biomass growth and $\beta$-carotene accumulation. At the first step the biomass is grown, and at the second step $\beta$-carotene accumulation is induced by elevated salinity, high irradiance and nutrient depletion [MASSJUK, 1973; BEN-AMOTZ, 1995].

Concentration of nutrients in natural brines is very low [OREN, 2009]. In the open pond culture one could easier control nutrient supply than salinity and irradiance. Brine evaporation rate and light intensity depend on climate, and are subject to seasonal and diurnal variations and weather fluctuations. To some extent, irradiance could be adjusted by changing pond depth [BHUMIBHAMON et al., 2003], and salinity - by pumping in fresh water [KOMARISTAYA et al., 2014] or bittern; but large pond area makes this technically difficult.

Salinity, irradiance, nitrate and phosphate supply might contribute unequally to biomass growth at the first step of cultivation, and to $\beta$-carotene accumulation at the second one. Coming from a fundamental principle of living systems organization as the scale-free networks [WOLF et al., 2002], D. salina cells must react significantly to some small number of environmental factors, moderately - to some intermediate number of them, and minimally to many the other that could be considered as noise. In biological systems factor effects very often interact, i.e. the response to one factor depends on the levels of the other factors [JONGMAN et al., 1995]. For economically feasible biosynthesis control in the open pond culture of $D$. salina, factors and their combinations must be chosen that are the most powerful and easily adjustable.

The literature disagrees on contribution of different factors into $\beta$-carotene biosynthesis in $D$. salina. Some researchers attach much importance to the impact of salinity and irradiance [LOEBLICH, 1982; BOROWITZKA, 2013], some other - to nutrient depletion [LERCHE, 1936/1937; COESEL et al., 2008]. Not all experiments confirm the effect of phosphorus deficiency [BEN-AMOTZ et al., 1982]. The literature data are fragmentary: some different combinations of some different factor level ranges were explored, sometimes on the natural, sometimes on the cultural material. As a rule, the alga was grown in the batch culture, that inevitably led to the confounding of the effects of factors-conditions (salinity and irradiance) with the effects of depleting factors-resources (nitrate and phosphate).

The purpose of this study was to quantify the contribution of salinity, irradiance, nitrate and phosphate and these factors interactions into the yield of cell number and $\beta$ carotene accumulation in $D$. salina culture.

Effect size $\eta^{2}$ - factor contribution into overall variance of a variable - was proposed as a statistical index [COHEN, 1973]. To investigate all possible combinations of factors and evaluate their main effects and interactions, the full factorial experimental design was used. To cover maximal factor level ranges, the two contrast levels of each factor were chosen: favorable for culture growth and for $\beta$-carotene accumulation. To avoid confounding of the effects of factors-conditions with the depletion of factors-resources, the alga was grown in fed-batch culture; nitrate and phosphate periodically supplied according to the known dynamics of their absorption [KOMARISTAYA et al., 2010]. To account for potential influence of inoculum nutrient status, the experiments were carried out in the two variants: on non- 
starved inoculum, pre-grown in standard nutrient supplied laboratory medium, and on starved inoculum, supported in nutrient deficient medium close to natural brine in composition.

\section{Materials and methods}

Dunaliella salina, strain IBSS1 received from the collection of Institute of Biology of Southern Seas (Sevastopol, Ukraine) in 2005 and cultured in our laboratory, was the object of study. Non-starved inoculum was grown in Artari medium in the modification of N.P. Massjuk [1973] containing $116 \mathrm{~g} \mathrm{~L}^{-1} \mathrm{NaCl}, 50 \mathrm{~g} \mathrm{~L}^{-1} \mathrm{MgSO}_{4} \cdot 7 \mathrm{H}_{2} \mathrm{O}, 2,5 \mathrm{~g} \mathrm{~L}^{-1} \mathrm{KNO}_{3}, 0,2 \mathrm{~g} \mathrm{~L}^{-1}$ $\mathrm{K}_{2} \mathrm{HPO}_{4}$. Starved inoculum was grown in the solution of natural sea salt with the density 1,15 $\mathrm{g} \mathrm{cm}^{-3}$. The inocula were cultivated under $5 \mathrm{klx}$ irradiance, photoperiod of 16 hours, and the temperature $27^{\circ} \mathrm{C}$.

The culture media for the experiments were prepared using $\mathrm{NaCl}$ and $\mathrm{MgSO}_{4} \cdot 7 \mathrm{H}_{2} \mathrm{O}$. Nitrogen and phosphorus were supplied as $\mathrm{KNO}_{3}$ and $\mathrm{K}_{2} \mathrm{HPO}_{4}$, respectively.

When inoculating, trace elements were added to the following final concentrations: 3,1 $\mathrm{mg} \mathrm{L} \mathrm{H}_{3}^{-1} \mathrm{BO}_{4}, 1,94 \mathrm{mg} \mathrm{L} \mathrm{MnSO}_{4} \cdot 5 \mathrm{H}_{2} \mathrm{O}, 0,287 \mathrm{mg} \mathrm{L} \mathrm{ZnSO}_{4} \cdot 7 \mathrm{H}_{2} \mathrm{O}, 0,088 \mathrm{mg} \mathrm{L}$ $\left(\mathrm{NH}_{4}\right)_{6} \mathrm{Mo}_{7} \mathrm{O}_{24} \cdot 4 \mathrm{H}_{2} \mathrm{O}, 0,146 \mathrm{mg} \mathrm{L}^{-1} \mathrm{Co}\left(\mathrm{NO}_{3}\right)_{2} \cdot 4 \mathrm{H}_{2} \mathrm{O}, 0,119 \mathrm{mg} \mathrm{L}^{-1} \mathrm{KBr}, 0,083 \mathrm{mg} \mathrm{L}^{-1} \mathrm{KI}$, $0,048 \mathrm{mg} \mathrm{L}^{-1} \mathrm{NiSO}_{4} \cdot 7 \mathrm{H}_{2} \mathrm{O}, 0,08 \mathrm{mg} \mathrm{L}^{-1} \mathrm{CuSO}_{4} \cdot 5 \mathrm{H}_{2} \mathrm{O}$.

The experiments were carried out according to the full factorial experimental design, 16 variants total. The design envisaged all possible combinations of 4 factors taken at 2 levels each: $\mathrm{K}_{2} \mathrm{HPO}_{4}$ - not added $\left(0 \mathrm{mg} \mathrm{L}^{-1}\right)$ and $10 \mathrm{mg} \mathrm{L}^{-1} ; \mathrm{KNO}_{3}$ - not added $\left(0 \mathrm{mg} \mathrm{L}^{-1}\right)$ and $80 \mathrm{mg}$ $\mathrm{L}^{-1}$; salinity $-1 \mathrm{M} \mathrm{NaCl}\left(0.1 \mathrm{M} \mathrm{MgSO}_{4} \cdot 7 \mathrm{H}_{2} \mathrm{O}\right.$ correspondingly) and $4 \mathrm{M} \mathrm{NaCl}(0,4 \mathrm{M}$ $\mathrm{MgSO}_{4} \cdot 7 \mathrm{H}_{2} \mathrm{O}$ correspondingly); irradiance $-2 \mathrm{klx}$ and $8 \mathrm{klx}$. Experimental design is shown in the legend to Fig. 1-4.

The cultures were periodically (every 3 days) fed by half initial doses of the nutrients according to previously studied dynamics of their absorption [KOMARISTAYA et al., 2010].

The light sources were "Maxus" lamps with the color temperature $2700 \mathrm{~K}$ : two $32 \mathrm{~W}$ lamps for $2 \mathrm{klx}$ and four $50 \mathrm{~W}$ lamps for $8 \mathrm{klx}$.

The cultures were inoculated to the initial cell count of about 25 thousand per $1 \mathrm{~mL}$ and cultivated in $25 \mathrm{~mL}$ Erlenmeyer flasks, $15 \mathrm{~mL}$ of culture in each, at 16 hours photoperiod and the temperature $27^{\circ} \mathrm{C}$.

Cell yields were registered on the $42^{\text {nd }}$ day of cultivation by counting the cells in Goryaev hemocytometer. Cell concentrations were calculated using the formula for the hemocytometer and expressed in millions per $1 \mathrm{~mL}$.

The rapid method of total carotenoids quantification was used, because it is fast, lowcost and can be easily applied in the field and at outdoor cultivation. The results obtained were interpreted as $\beta$-carotene content, because $D$. salina is known to accumulate mainly $\beta$ carotene [JIMENEZ, PICK, 1994]. Extraction was performed on the $42^{\text {nd }}$ day of cultivation by vigorous shaking culture aliquot $(1 \mathrm{~mL})$ with $2 \mathrm{~mL}$ of ethyl acetate. $\beta$-carotene content was quantified by absorbance of the extracts at $440 \mathrm{~nm}$, calculated using the reference extinction value $\mathrm{E}_{1 \mathrm{~cm}}{ }^{1 \%}=2500$ [IARC, 1998] and expressed in pg per cell.

The experiments were carried out in triplicate. According to Shapiro-Wilk test the distribution of data differs insignificantly from the normal. The parametric statistic tests were used: multivariate analysis of variance and $\mathrm{F}$ value - to assess the significance of the effects of individual factors and their interactions, effect sizes $\eta^{2}$ (rounded to 2 decimals) - to assess their input into overall variance of the variables. The plots show mean values and Fisher's least significance differences (LSD), which were used to compare means. Discussed differences are significant at $95 \%$ level. 


\section{Results}

Dunaliella salina cells survived and remained in the vegetative phase during 42 days in all the experimental variants, including even starved inoculum in the nutrient deficient media. Starved and non-starved inocula had similarities and differences in the patterns of effect sizes of the factors and their interactions (tabl. 1).

Table 1

Effect sizes $\eta^{2}$ of $\mathrm{KNO}_{3}, \mathrm{~K}_{2} \mathrm{HPO}_{4}$, salinity, irradiance and their interactions onto concentration of cells and cellular $\beta$-carotene content in 42-day $D$. salina culture inoculated by non-starved and starved inocula

\begin{tabular}{|c|c|c|c|c|c|c|c|c|}
\hline \multirow[b]{3}{*}{ Factor } & \multicolumn{4}{|c|}{ Concentration of cells } & \multicolumn{4}{|c|}{ Cellular $\beta$-carotene content } \\
\hline & \multicolumn{2}{|c|}{$\begin{array}{l}\text { Non-starved } \\
\text { inoculum }\end{array}$} & \multicolumn{2}{|c|}{$\begin{array}{c}\text { Starved } \\
\text { inoculum }\end{array}$} & \multicolumn{2}{|c|}{$\begin{array}{l}\text { Non-starved } \\
\text { inoculum }\end{array}$} & \multicolumn{2}{|c|}{$\begin{array}{c}\text { Starved } \\
\text { inoculum }\end{array}$} \\
\hline & $\eta^{2}$ & $\mathrm{~F}$ & $\eta^{2}$ & $\mathrm{~F}$ & $\eta^{2}$ & $\mathrm{~F}$ & $\eta^{2}$ & $\mathrm{~F}$ \\
\hline 1 & 2 & 3 & 4 & 5 & 6 & 7 & 8 & 9 \\
\hline $\mathrm{KNO}_{3}$ & $0,19 *$ & 422,48 & $0,18 *$ & 23,59 & $0,07 *$ & 24,80 & 0,01 & 3,53 \\
\hline $\mathrm{K}_{2} \mathrm{HPO}_{4}$ & $0,23 *$ & 512,66 & $0,13 *$ & 16,36 & $0,56^{*}$ & 187,63 & $0,36^{*}$ & 98,67 \\
\hline $\mathrm{KNO}_{3}$ and $\mathrm{K}_{2} \mathrm{HPO}_{4}$ & $0,17 *$ & 379,86 & $0,12 *$ & 14,91 & $0,08 *$ & 26,51 & $0,21 *$ & 58,80 \\
\hline Salinity & $0,05^{*}$ & 120,85 & $0,09 *$ & 12,14 & 0,01 & 3,19 & $0,05^{*}$ & 13,59 \\
\hline Salinity and $\mathrm{KNO}_{3}$ & $0,07 *$ & 150,39 & $0,07 *$ & 9,58 & 0,00 & 0,11 & $0,13 *$ & 35,49 \\
\hline Salinity and $\mathrm{K}_{2} \mathrm{HPO}_{4}$ & $0,10^{*}$ & 226,63 & $0,05^{*}$ & 5,88 & $0,10^{*}$ & 33,35 & $0,01 *$ & 3,71 \\
\hline Salinity, $\mathrm{KNO}_{3}$ and $\mathrm{K}_{2} \mathrm{HPO}_{4}$ & $0,08 *$ & 175,68 & $0,04 *$ & 5,40 & 0,01 & 2,59 & 0,00 & 0,00 \\
\hline Irradiance & $0,03 *$ & 66,83 & 0,00 & 0,26 & $0,08 *$ & 28,16 & 0,00 & 1,30 \\
\hline Irradiance and $\mathrm{KNO}_{3}$ & $0,01 *$ & 14,08 & 0,00 & 0,35 & 0,00 & 0,18 & $0,03 *$ & 8,48 \\
\hline Irradiance and $\mathrm{K}_{2} \mathrm{HPO}_{4}$ & $0,02 *$ & 37,95 & 0,00 & 0,00 & $0,02 *$ & 7,82 & $0,05 *$ & 13,73 \\
\hline Irradiance, $\mathrm{KNO}_{3}$ and $\mathrm{K}_{2} \mathrm{HPO}_{4}$ & $0,01 *$ & 17,99 & 0,00 & 0,01 & 0,00 & 1,03 & $0,02 *$ & 4,17 \\
\hline Salinity and irradiance & $0,02 *$ & 54,80 & 0,03 & 3,88 & 0,01 & 2,23 & 0,00 & 0,62 \\
\hline Salinity, irradiance, $\mathrm{KNO}_{3}$ & $0,01 *$ & 19,90 & 0,02 & 3,10 & 0,00 & 0,20 & 0,00 & 0,02 \\
\hline Salinity, irradiance, $\mathrm{K}_{2} \mathrm{HPO}_{4}$ & $0,02 *$ & 34,06 & 0,00 & 0,42 & 0,00 & 0,35 & 0,01 & 1,60 \\
\hline $\begin{array}{r}\text { Salinity, irradiance, } \mathrm{KNO}_{3} \text { and } \\
\mathrm{K}_{2} \mathrm{HPO}_{4}\end{array}$ & $0,01 *$ & 16,96 & 0,00 & 0,62 & 0,00 & 0,04 & 0,00 & 0,09 \\
\hline
\end{tabular}

Note: $*$ - $\mathrm{F} \geq \mathrm{F}_{\text {tabl. }}\left(\mathrm{p} \leq 0,05, \mathrm{df}_{1}=1, \mathrm{df}_{2}=32, \mathrm{~F}_{\text {tabl }}=4,15\right)$

In the culture grown from non-starved inoculum, all the factors and interactions influenced cell yield, though their majority contributed into the total variance no more than $3 \%$ (tab. 1). Nitrate, phosphate and their combination influenced cell yield most strongly (tabl. 1).

In the culture grown from starved inoculum, the nutrients led by their effect sizes on cell yield too. The contribution of salinity increased; the effects of nitrate and its interaction with salinity maintained the same level (tabl. 1). All the effects related to phosphate decreased compared with non-starved inoculum (tabl. 1). The main effects and interactions related to irradiance dropped out from the statistically significant (tabl. 1).

The data on cell yields confirmed and detailed the effect size pattern.

For the both inocula one or two nutrients deficiency significantly decreased cell yield (Fig. 1, 2). In the variants supplied with the both nutrients, high salinity inhibited culture density increase but less than nutrient deficiency (Fig. 1, 2). High irradiance increased cell concentration at low salinity and the both nutrients supply, but this effect appeared statistically significant for non-starved inoculum only (Fig. 1).

As to $\beta$-carotene accumulation, in the culture grown from non-starved inoculum, the number of significant main effects and interactions decreased compared with the cell yields. The nutrients kept the lead, especially phosphate, which contributed 56\% into the variance of that variable (tabl. 1). Salinity influenced $\beta$-carotene accumulation only combined with phosphate (tabl. 1). 


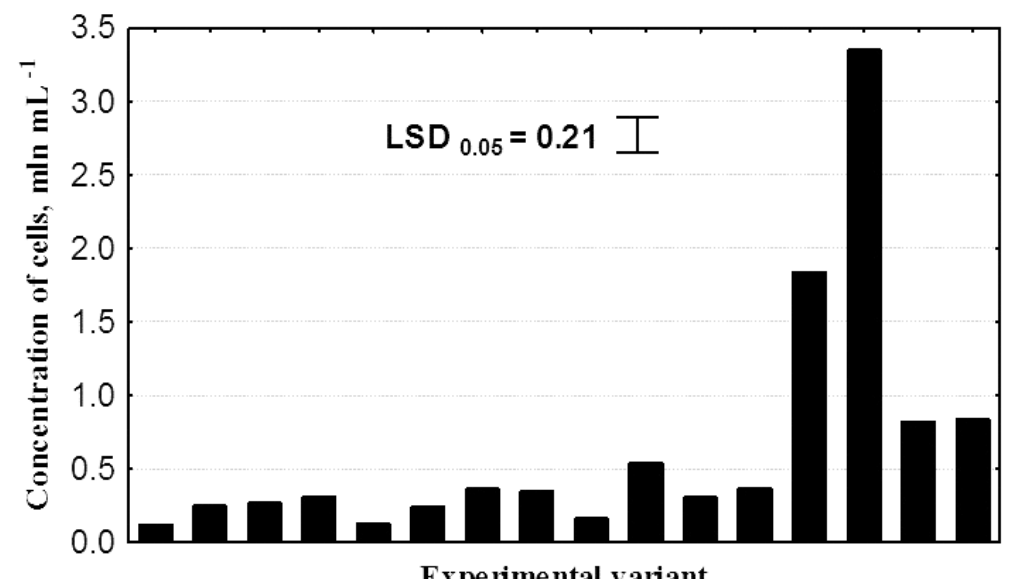

Experimental variant

\begin{tabular}{|c|c|c|c|c|c|c|c|c|c|c|c|c|c|c|c|c|}
\hline $\mathrm{K}_{2} \mathrm{HPO}_{4}, \mathrm{mg} \mathrm{L}^{-1}$ & \multicolumn{7}{|c|}{0} & & \multicolumn{8}{|c|}{10} \\
\hline $\mathrm{KNO}, \mathrm{mg} \mathrm{L}^{-1}$ & \multicolumn{4}{|c|}{0} & \multicolumn{4}{|c|}{80} & \multicolumn{4}{|c|}{0} & \multicolumn{4}{|c|}{80} \\
\hline $\mathrm{NaCl}, \mathrm{M}$ & & & & & & & & & & & & & & & & \\
\hline Irradiance, klx & 2 & 8 & 2 & 8 & 2 & 8 & 2 & 8 & 2 & 8 & 2 & 8 & 2 & 8 & & 8 \\
\hline
\end{tabular}

Fig. 1. Concentrations of cells on the $42^{\text {nd }}$ day of cultures inoculated with non-starved inoculum in the variants of full factorial experimental design.

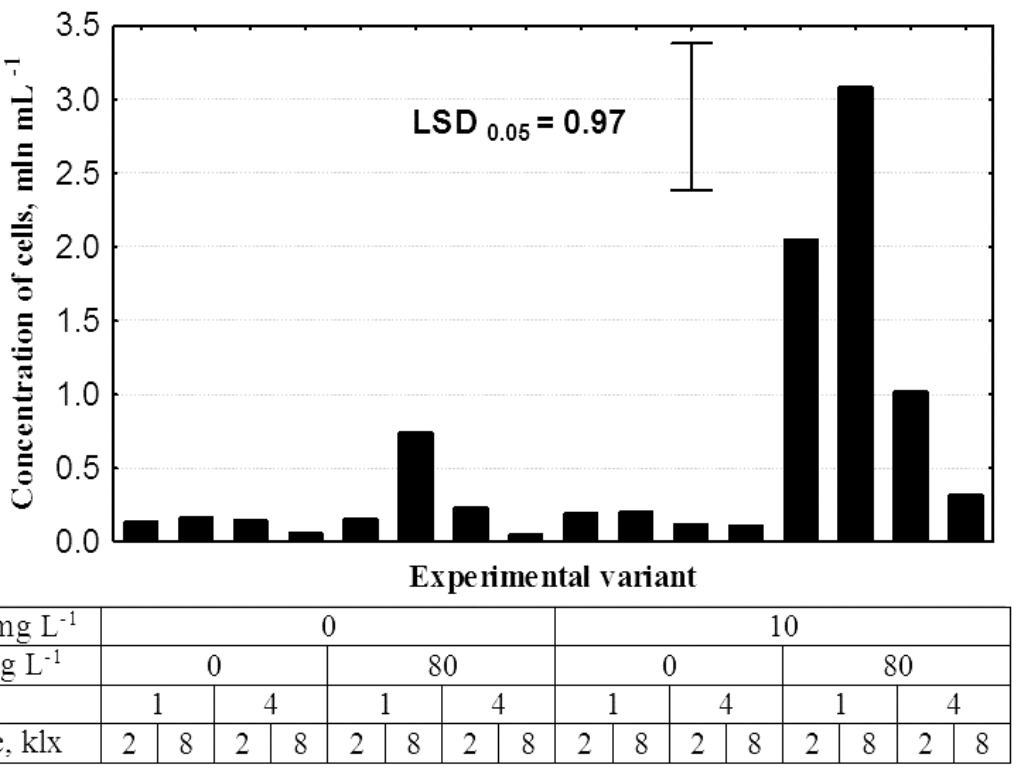

Fig. 2. Concentrations of cells on the 42nd day of cultures inoculated with starved inoculum in the variants of full factorial experimental design.

Compared with the effect on cell yields, the main effect of irradiance more than doubled; interaction with phosphate remained the only significant interaction of irradiance (tabl. 1).

In the culture grown from starved inoculum, nutrients still kept the lead, though phosphate contributed $20 \%$ less, and nitrate affected insignificantly, but they interact more strongly (tabl. 1). On the contrary to non-starved inoculum, the main effect of salinity gained significance, and the main effect of irradiance lost it (tabl. 1). Salinity interacted more strongly with nitrate than with phosphate (tabl. 1). The effect of irradiance depended on nutrients, at that, irradiance interacted with phosphate more strongly, than with nitrate or with both the nutrients (tabl. 1).

For non-starved inoculum, $\beta$-carotene content values showed that the lack of any or both the nutrients induced significant $\beta$-carotene accumulation compared with corresponding variants supplied with the nutrients (Fig. 3). At phosphate or the both nutrients deficiency, elevated salinity negatively impacted $\beta$-carotene accumulation (Fig. 3). 


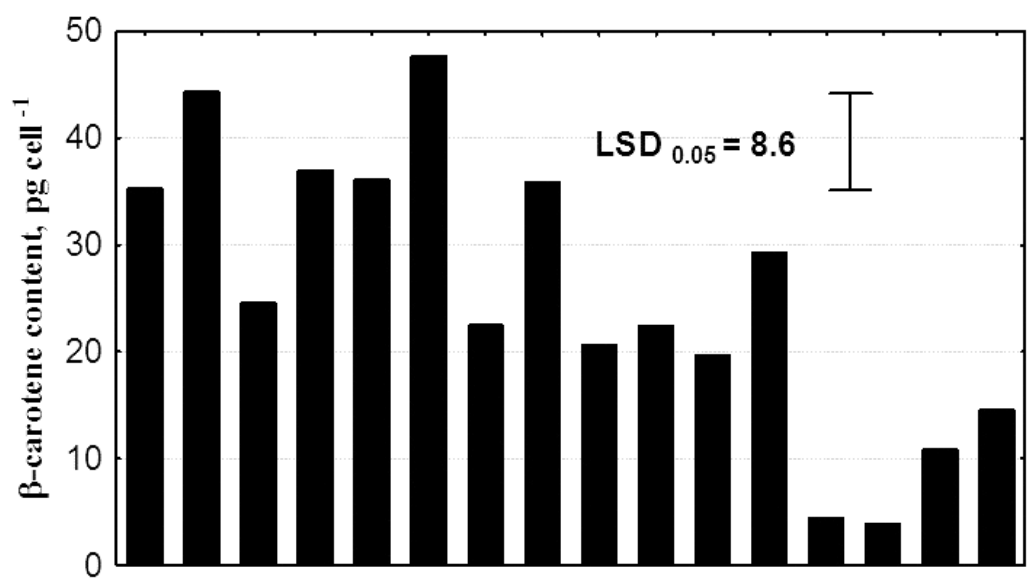

Experimental variant

\begin{tabular}{|c|c|c|c|c|c|c|c|c|c|c|c|c|c|c|c|c|}
\hline $\mathrm{K}_{2} \mathrm{HPO}_{4}, \mathrm{mg} \mathrm{L}^{-1}$ & \multicolumn{8}{|c|}{0} & \multicolumn{8}{|c|}{10} \\
\hline $\mathrm{KNO} 3, \mathrm{mg} \mathrm{L}^{-1}$ & \multicolumn{4}{|c|}{0} & \multicolumn{4}{|c|}{80} & \multicolumn{4}{|c|}{0} & \multicolumn{4}{|c|}{80} \\
\hline $\mathrm{NaCl}, \mathrm{M}$ & & & & & & & & & & & & & & & & \\
\hline Irradiance, klx & 2 & 8 & 2 & 8 & 2 & 8 & 2 & 8 & 2 & 8 & 2 & 8 & 2 & 8 & 2 & 8 \\
\hline
\end{tabular}

Fig. 3. Cellular $\beta$-carotene content on the 42nd day of cultures inoculated with non-starved inoculum in the variants of full factorial experimental design.

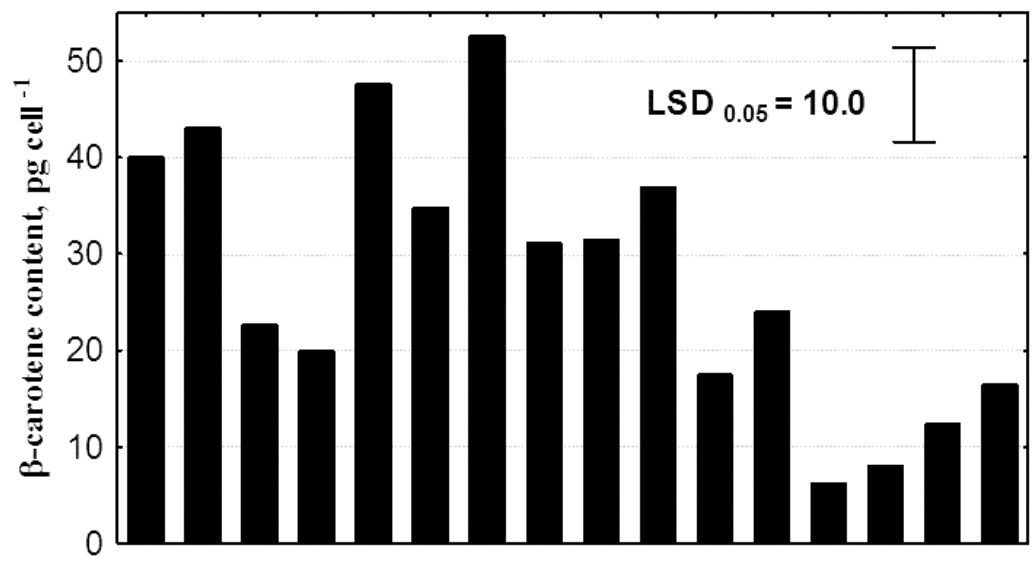

Experimental variant

\begin{tabular}{|c|c|c|c|c|c|c|c|c|c|c|c|c|c|c|c|c|}
\hline $\mathrm{K}_{2} \mathrm{HPO}_{4}, \mathrm{mg} \mathrm{L}^{-1}$ & \multicolumn{8}{|c|}{0} & \multicolumn{8}{|c|}{10} \\
\hline $\mathrm{KNO}_{3}, \mathrm{mg} \mathrm{L}^{-1}$ & \multicolumn{4}{|c|}{0} & \multicolumn{4}{|c|}{80} & \multicolumn{4}{|c|}{0} & \multicolumn{4}{|c|}{80} \\
\hline $\mathrm{NaCl}, \mathrm{M}$ & & & & & & & & & & & & & 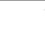 & & & 4 \\
\hline Irradiance, klx & 2 & 8 & 2 & 8 & 2 & 8 & 2 & 8 & 2 & 8 & 2 & 8 & 2 & 8 & 2 & 8 \\
\hline
\end{tabular}

Fig. 4. Cellular $\beta$-carotene content on the 42nd day of cultures inoculated with starved inoculum in the variants of full factorial experimental design.

In starved inoculum any or the both nutrients deficiency induced $\beta$-carotene accumulation too (Fig. 4). Salinity impaired $\beta$-carotene accumulation at the deficiency of nitrate or the both nutrients deficiency (Fig. 4). Stimulating effect of irradiance on $\beta$-carotene accumulation disappeared in starved inoculum; at phosphate deficiency high irradiance even decreased $\beta$-carotene content (Fig. 4).

At phosphate or the both nutrients supply, impact of elevated salinity changed to neutral or, at high irradiance, to positive (Fig. 3). At phosphorus deficiency, or the both nutrients deficiency, high irradiance stimulated $\beta$-carotene accumulation (Fig. 3).

For the both inocula, the variants, supplied with the two nutrients, tended to accumulate $\beta$-carotene at high salinity. This effect reached statistical significance $(p \leq 0,05)$ at high irradiance (Fig. 3, 4). 


\section{Discussion}

We found that such nutrients as nitrogen and phosphorus influence productivity of Dunaliella salina culture by cell yield and $\beta$-carotene accumulation more strongly than salinity and irradiance. That means, that controlled supply of nutrients would be the most effective way of biosynthesis control in D. salina culture. This finding is novel, because we were the first who clearly eliminated confounding of the effects of factors-conditions and factors-resources and evaluated independent contribution of each factor and interaction with $\eta^{2}$. The same way, we isolated the synergistic effect of salinity and irradiance, unconfounded by nutrient depletion, though at that cells accumulated less $\beta$-carotene than at nutrients deficiency.

In most experimental variants the size of the main effects of salinity and irradiance fell behind their interactions with the nutrients. That means, that adjustments in nutrients supply may correct effects of changes in salinity and irradiance caused by weather in open pond culture.

Pre-supply of the inocula with nutrients influenced the sign of interactions of factorsconditions with the deficiencies of factors-resources. In non-starved inoculum high irradiance stimulated $\beta$-carotene accumulation, in starved - diminished or left unaffected. High salinity in most cases impaired $\beta$-carotene accumulation induced by nutrient deficiencies, especially in starved inoculum. Extreme nutrient depletion (starved inoculum under nutrients deficiency) seemed to impair $\beta$-carotene accumulation at high salinity or irradiance. That means, that in open pond culture under irradiance and salinity fluctuations, culture nutrient status should be constantly monitored and nutrient supply adjusted.

In her classical study [LERCHE, 1936-37] first showed that $D$. salina cells gained red color due to $\beta$-carotene accumulation in droplets inside the chloroplast under nitrogen, phosphorus, or the both nutrients deficiency.

In the following years of $D$. salina research, almost all scientific literature overlooked the determining role of nutrients depletion in $\beta$-carotene accumulation in D. salina cells. It seemed that unique ecological niche inhabited by $D$. salina distracted researchers' attention to its extreme parameters - salinity and irradiance. D. salina ability to sustain long under nutrients depletion went unnoticed; and nutrients always were added to the media by default, at least in trace amounts. By this reason, numerous reports about induction of $\beta$-carotene accumulation by elevated salinity [LOEBLICH, 1982; BOROWITZKA et al., 1990], high irradiance [LOEBLICH, 1982; BEN-AMOTZ, AVRON, 1983; LERS et al., 1990] or by their synergistic action [BEN-AMOTZ, AVRON, 1990; ARAÚJO et al., 2009] were not free from confounding with the effects of nutrients depletion in regular batch culture. At best, authors discussed cooperative effects of salinity or irradiance with nutrients depletion [BEN-AMOTZ, 1987; MARÍn et al., 1998].

Very few experiments were carried out under nutrients medium concentrations control, like gene expression studies of the key enzymes in isoprenoid (MEP methylerythritol phosphate pathway) and carotenoid biosynthetic pathway in D. salina. Nutrients deficiency, especially at high salinity or irradiance, upregulated transcript levels of HDR (4-hydroxy-3-methylbut-2-enyl diphosphate reductase, EC: 1.17.1.2) [RAMOS et al., 2009], Psy (phytoene synthase, EC: 2.5.1.32) and Pds (phytoene desaturase, EC: 1.3.5.5) [COESEL et al., 2008], and Lcy- $\beta$ (lycopene beta-cyclase, EC: 5.5.1.19) [RAMOS et al., 2008]. $\beta$-carotene content mainly followed the same tendency [COESEL et al., 2008]. Our data on $\beta$ carotene accumulation in the free of nutrients culture media confirmed that pattern.

This molecular data brought the authors to the conclusion that nutrient depletion is necessary and sufficient for induction of $\beta$-carotene accumulation in D. salina cells at transcriptional level [COESEL et al., 2008]. Our data add to this finding that nutrient 
deficiencies contribute into $\beta$-carotene accumulation quantitatively much more than salinity and irradiance.

Cited studies [COESEL et al., 2008; RAMOS et al., 2008; 2009] showed that factorsconditions interacted with factors-resources at transcriptional level. Signal transduction network might be supposed, providing interactions of the signals and modulation of the effect.

At nutrients supply salt and light stress induced lower expression of $L c y-\beta$ [RAMOS et al., 2008], but unaltered HDR [RAmOs et al., 2009], Psy and Pds [COESEL et al., 2008]. At that, $\beta$-carotene accumulated less and not always. Our experiments showed distinct $\beta$-carotene accumulation at high salinity and high irradiance against the background of nutrients supply. Synergistic effect of salinity and irradiance was confirmed in some studies [ARAÚJO et al., 2009], but was not investigated at the gene expression level.

The effects of salinity and irradiance might be mediated by their influence on nutrients absorption by the cells. Elevated salinity slowed nitrate absorption down [COESEL et al., 2008; RAMOS et al., 2008], but high irradiance either not affected or accelerated its rate up [RAMOS et al., 2008]. The authors recorded nitrate concentration dynamics [COESEL et al., 2008; RAMOS et al., 2008; 2009], though diluted the medium with water and actually observed the deficiency of several nutrients (phosphorus being the primary concern as a macronutrient). We confirmed after LERCHE [1936/1937] $\beta$-carotene accumulation induced by phosphorus depletion [KOMARISTAYA et al., 2010]; its mechanism still remains unresolved.

According to RAMOS et al. [2009] too severe nitrogen deficiency (absolute exclusion of nitrogen from the medium) was responsible for downregulation of $D X S$ (1-deoxy-Dxylulose 5-phosphate synthase, EC: 2.2.1.7) - the first enzyme in MEP pathway, and for nonsusceptibility of Psy - the first enzyme in carotenoid biosynthesis pathway in [SÁNCHEZESTUDILLO et al., 2006]. It agrees with our data showed that nutrient status of inoculum changes the sign of some effects of salinity and irradiance on $\beta$-carotene accumulation.

Most of mechanisms involved in $\beta$-carotene accumulation in D. salina remain obscure: sensing environmental signals, signal transduction network, transcriptional and posttranscriptional regulation and functions of accumulated $\beta$-carotene [LAMERS et al., 2008].

Signaling process might involve reactive oxygen species (ROS), e.g. singlet oxygen [SHAISH et al., 1993]. Gene expression is necessary to induce $\beta$-carotene accumulation [BENAMOTZ et al., 1988; LERS et al., 1990]. Metabolic-sink mechanism could participate in posttranslational regulation [RABBANI et al., 1998]. D. salina cells accumulate $\beta$-carotene in lipid bodies inside the chloroplast (plastoglobuli), which contain mostly triacylglycerols [BENAMOTZ et al., 1982]. Inhibition of triacylglycerols synthesis prevents $\beta$-carotene from accumulating. Thus, plastoglobuli might sequester $\beta$-carotene avoiding end-product inhibition of the carotenoid pathway [RABBANI et al., 1998].

Many algal species [ROESSLER, 1990], including D. salina [GIORDANO et al., 2015], were shown to accumulate triacylglycerols under nitrogen starvation. We hypothesize that not only nitrogen, but phosphorus depletion as well, might re-distribute metabolic fluxes to accumulation of triacylglycerols when $\mathrm{C}: \mathrm{N}: \mathrm{P}$ ratio shifts pro $\mathrm{C}$. Our suggestion agrees well with revealed high contribution of both the nutrients deficiencies into $\beta$-carotene accumulation.

Several hypotheses were suggested to explain the role of $\beta$-carotene in $D$. salina plastoglobuli: the screen against excess light and blue region of the spectrum [BEN-AMOTZ et al., 1989], the scavenger of free radicals [SHAISH et al., 1993], the precursor of sporopollenin in cell walls of resting stages [KOMARISTAYA, GORBULIN, 2006], or of abscisic acid-like signaling molecules [COWAN, Rose, 1991], or combination thereof.

Coming from our study, the function of accumulated $\beta$-carotene is likely to relate to mineral nutrition and, to the lesser extent, to adaptation to extreme environment, e.g. protection of storage triacylglycerols from peroxidation. 
This study relied on some assumptions. The first assumption: in all experimental variants the dynamics of nutrients absorption corresponded to previously established for intermediate salinity and irradiance $\left(2 \mathrm{M} \mathrm{NaCl}, 0.2 \mathrm{M} \mathrm{MgSO}_{4} \cdot 7 \mathrm{H}_{2} \mathrm{O}, 5 \mathrm{klx}\right)$ [KOMARISTAYA et al., 2010]. This dynamics governed fed-batch cultivation in the present study. Influence of salinity and irradiance on absorption and metabolism of nitrate and phosphate in D. salina cells needs further investigation. Nevertheless, robustness of present study was confirmed by the fact that the culture equally responded to nitrate doses $20-80 \mathrm{mg} \mathrm{L}^{-1}$ and phosphate doses 4-9 $\mathrm{mg} \mathrm{L}^{-1}$ [KOMARISTAYA et al., 2010].

The second assumption: both inside and outside the investigated ranges of factor levels (including time point 42 day and the 2 nutritional states of the inocula) the biological system would respond smoothly, without any local minima or maxima, which could increase the relative contribution of salinity or irradiance compared with the nutrients. We selected the level ranges of factors to study, based on previous investigations of natural habitatas of $D$. salina [KOMARISTAYA et al., 2014], including irradiance, which can reach $100 \mathrm{klx}$ at brine surface at clear summer midday, but at several $\mathrm{cm}$ depth, under cloudiness, most of the daytime and year irradiance, it approaches the level range studied [KOMARISTAYA et al., 2014]. The response of $D$. salina culture to different factor levels requires further detailed research in full factorial experimental design. Our previous studies in the narrower level ranges of factors $\left(0,20,40\right.$ and $80 \mathrm{mg} \mathrm{L}^{-1} \mathrm{KNO}_{3} ; 0,4$ and $9 \mathrm{mg} \mathrm{L}^{-1} \mathrm{KH}_{2} \mathrm{PO}_{4} ; 2 \mathrm{M} \mathrm{NaCl} ; 5 \mathrm{klx}$; starved inoculum; 42 day of culture [KOMARISTAYA et al., 2010], and 0 and $80 \mathrm{mg} \mathrm{L}^{-1} \mathrm{KNO}_{3}$; 0 and $9 \mathrm{mg} \mathrm{L}^{-1} \mathrm{KH}_{2} \mathrm{PO}_{4} ; 2$ and $4 \mathrm{M} \mathrm{NaCl} ; 2$ and $5 \mathrm{klx}$; starved inoculum; 28 day of culture [MIL'KO et al., 2011]) showed high reproducibility of prevailing effects of nutrients over salinity and irradiance.

Thus, comparison to earlier studies confirms high reliability of nutrients effect and points out the necessity to further investigate interaction mechanisms of factors-conditions and factors-resources, as well as to find metabolic parameters that could reflect nutrient saturation of the cells and predict culture response to salinity and irradiance variations. Ultimately, predictive model of culture growth and $\beta$-carotene accumulation based on absorbed C:N:P stoichiometry could be developed to serve for biosynthesis control in fedbatch culture. This model would be used to calculate necessary nutrients doses to fit cells state and dynamically changing conditions in open pond culture.

The model would also help to elucidate the mechanisms of red "bloom" in hyperhaline waters, that have both cognitive and aesthetic value.

Some more factors known as inducers of $\beta$-carotene accumulation in $D$. salina were beyond the scope of this study, e.g., sulfur deficiency and suboptimal temperature. We believe that sulfur deficiency is irrelevant in coastal lagoons and solar salterns because the brine contains high concentration of sulfate [HOLLAND, 1978]. Temperature is poorly studied as the factor inducing $\beta$-carotene accumulation [MENDOZA et al., 1996]; it needs more research and, possibly, incorporation into the model.

During the last 50 years because of emerging alternative salt manufacturing technologies, profit loss and termination of salterns operations, 57\% of 70000 ha of hyperhaline lakes were lost in Mediterranean [LÓPEZ et al., 2010]. Without sea water supply salterns lose their gradients, suffer uncontrolled salinity increase and dry out, and later, because of unattended levees destruction - undergo desalinization. This process leads to loss of habitats for many hyperhalobe species (archaea, prokaryotes, algae, invertebrates), and of places of rest, feeding and breeding for migrating water birds [LÓPEZ et al., 2010].

Solar salterns is a unique kind of ecosystem that is regulated by human [BELLISARIO et al., 2010]. Implementation of D. salina cultivation technology would not only increase proportion of natural carotenoids in human diet; it could be one of support means for economic attractiveness of salterns and their conservation. 


\section{Conclusions}

1. In the investigated factor level ranges (irradiance 2-8 klx, salinity $1-4 \mathrm{M} \mathrm{NaCl}$, $\mathrm{KNO}_{3} 0-80 \mathrm{mg} \mathrm{L}^{-1}, \mathrm{~K}_{2} \mathrm{HPO}_{4} 0-10 \mathrm{mg} \mathrm{L}^{-1}$ ), the nutrients (nitrogen and phosphorus) influence culture productivity by cells number and $\beta$-carotene accumulation in D. salina more strongly than salinity and irradiance.

2. Combination of elevated salinity and high irradiance exerts its own, unconfounded with depletion of nutrients, but lower inducing effect onto $\beta$-carotene accumulation.

3 . Effects of salinity and irradiance on cell yield and intracellular $\beta$-carotene content depended on nutrients and their pre-supply to the inoculum.

\section{References}

Araúuo O.Q.F., Gobbi C.N., Chaloub R.M., Coelho M.A.Z. (2009). Assessment of the impact of salinity and irradiance on the combined carbon dioxide sequestration and carotenoids production by Dunaliella salina: a mathematical model. Biotechnology and bioengineering, 102 (2): 425-435. doi: 10.1002/bit.22079

Bellisario B., Novelli C., Cerfolli F., Angeletti D., Cimmaruta R., Nascetti G. (2010). The ecological restoration of the Tarquinia salterns drives the temporal changes in the benthic community structure. Transitional Waters Bulletin, 4 (2): 105-114. doi: 10.1285/i1825229Xv4n1p105

BeN-Amotz A. (1987). Effect of irradiance and nutrient deficiency on the chemical composition of Dunaliella bardawil Ben-Amotz and Avron (Volvocales, Chlorophyta). Journal of plant physiology, 131 (5): 479-487. doi: 10.1016/S0176-1617(87)80290-0

Ben-Amotz A. (1995). New mode of Dunaliella biotechnology: two-phase growth for $\beta$-carotene production. Journal of applied phycology, 7 (1): 65-68. doi: 10.1007/BF00003552

BEN-AMOTZ A. (2004). Industrial production of microalgal cell-mass and secondary products - major industrial species. In: Handbook of microalgal culture: Biotechnology and Applied Phycology: 273-280. UK, Oxford, Blackwell Sciencedoi. doi: 10.1002/9780470995280.ch13

Ben-Amotz A. (2009). Bio-fuel and $\mathrm{CO}_{2}$ capture by algae. ANR meeting on «Third Generation Biofuels», Paris, France, February 5, 2015: 80 p.

Ben-Amotz A., Avron M. (1983). On the factors which determine massive $\beta$-carotene accumulation in the halotolerant alga Dunaliella bardawil. Plant Physiology, 72 (3): 593-597. doi: 10.1104/pp.72.3.593

Ben-Amotz A., Avron M. (1990). The biotechnology of cultivating the halotolerant alga Dunaliella. Trends in Biotechnology, 8: 121-126. doi: 10.1016/0167-7799(90)90152-N

Ben-Amotz A., KATZ A., AvRon M. (1982). Accumulation of $\beta$-carotene in halotolerant algae: purification and characterization of $\beta$-carotene-rich globules from Dunaliella bardawil. Journal of Phycology, 18 (4): 529-537. doi: 10.1111/j.1529-8817.1982.tb03219.x

Ben-Amotz A., Lers A., AVRon M. (1988). Stereoisomers of $\beta$-carotene and phytoene in the alga Dunaliella bardawil. Plant physiology, 86 (4): 1286-1291. doi: 10.1104/pp.86.4.1286

Ben-Amotz A., Shaish A., AVRON M. (1989). Mode of action of the massively accumulated $\beta$-carotene of Dunaliella bardawil in protecting the alga against damage by excess irradiation. Plant Physiology, 91 (3): 1040-1043. doi: 10.1104/pp.91.3.1040

Bhumibhamon O., SitTiphuprasert U., Boontaveeyuwat N., Praiboon J. (2003). The optimum use of salinity, nitrate and pond depth for $\beta$-carotene production of Dunaliella salina. Kasetsart Journal: Natural Sciences, 37 (1): 84-89.

BorowitzKa M.A. (1999). Commercial production of microalgae: ponds, tanks, and fermenters. Progress in industrial microbiology, 35: 313-321. doi: 10.1016/S0079-6352(99)80123-4

BOROWITZKA M.A. (2013). Dunaliella: biology, production, and markets. In: Handbook of microalgal culture: Biotechnology and Applied Phycology: 359-368. UK, Oxford, Blackwell Sciencedoi. doi: 10.1002/9781118567166.ch18

BorowitzKa M.A., BOROWITZKA L.J., KeSSLY D. (1990). Effects of salinity increase on carotenoid accumulation in the green alga Dunaliella salina. Journal of Applied Phycology, 2 (2): 111-119. doi: 10.1007/BF00023372

Coesel S.N., Baumgartner A.C., Teles L.M., Ramos A.A., Henriques N.M., Cancela L., Varela J.K.S. (2008). Nutrient limitation is the main regulatory factor for carotenoid accumulation and for Psy and $P d s$ steady state transcript levels in Dunaliella salina (Chlorophyta) exposed to high light and salt stress. Marine Biotechnology, 10 (5): 602-611. doi: 10.1007/s10126-008-9100-2

COHEN J. (1973). Eta-squared and partial eta-squared in fixed factor ANOVA designs. Educational and Psychological Measurement, 33 (1): 107-112. doi: 10.1177/001316447303300111 
COWAN A.K., Rose P.D. (1991). Abscisic acid metabolism in salt-stressed cells of Dunaliella salina. Possible interrelationship with $\beta$-carotene accumulation. Plant physiology, 97 (2): 798-803. doi: 10.1104/pp.97.2.798

CURTAin C. (2000). Plant Biotechnology - the growth of Australia's algal $\beta$-carotene industry. Australasian Biotechnology, 10 (3): 19-23.

Del Campo J.A., García-GonzÁlez M., Guerrero M.G. (2007). Outdoor cultivation of microalgae for carotenoid production: current state and perspectives. Applied microbiology and biotechnology, 74 (6): 1163-1174. doi: 10.1007/s00253-007-0844-9

EFSA Panel on Food Additives and Nutrient Sources added to food (ANS). (2012). Scientific Opinion on the reevaluation of mixed carotenes (E 160a (i)) and $\beta$-carotene (E 160a (ii)) as a food additive. EFSA Journal, 10 (3): 25-93doi: 10.2903/j.efsa.2012.2593

Giordano M., Palmucci M., Norici A. (2015). Taxonomy and growth conditions concur to determine the energetic suitability of algal fatty acid complements. Journal of Applied Phycology, 27 (4): 14011413. doi: 10.1007/s10811-014-0457-5

HOLLAND H.D. (1978). The chemistry of the atmosphere and oceans, Vol.1. New-York, USA: Wiley, 351 p.

IARC Working Group on the Evaluation of Cancer Preventive Agents. (1998). IARC Handbook on Cancer Prevention, Vol.2: Carotenoids. Lyon, France: IARC, 326 p.

JiMENEZ C., PICK U. (1994). Differential stereoisomer compositions of $\beta$, $\beta$-carotene in thylakoids and in pigment globules in Dunaliella. Journal of plant physiology, 143 (3): 257-263. doi: 10.1016/S01761617(11)81628-7

JONGMAN R.H.G., TER BRAAK C.J.F., VAN TONGEREN O.F.R. (1995). Data analysis in community and landscape ecology. Cambridge, UK: Cambridge university press, $324 \mathrm{p}$.

KomARISTAYA V.P., ANTONENKO S.P., RUDAS A.N. (2010). Cultivation of Dunaliella salina Teod. at suboptimal concentrations and exclusion of nitrogen and phosphorus from the medium. Algologia, 20 (1): 4255. (in Russian).

KOMARISTAYA V.P., GORBULIN O.S. (2006). Sporopollenin in the composition of cell walls of Dunaliella salina Teod. (Chlorophyta) zygotes. International Journal on Algae, 8 (1): 43-52. doi: 10.1615/InterJAlgae.v8.i1.40

Komaristaya V.P., Rudas A.A., Tatischeva N.M., TatischeV E.V., Rudas A.N. (2014). Ecological peculiarities of natural populations of hyperhalobe microalga Dunaliella salina Teod. in solar salt work ponds of the South of Ukraine and Russia. The Journal of V.N. Karazin Kharkiv National University. Series: Biology, 20 (1100): 315-323.

LAMERS P.P., JANSSEN M., DE Vos R.C., BINO R.J., WiJfFELS R.H. (2008). Exploring and exploiting carotenoid accumulation in Dunaliella salina for cell-factory applications. Trends in biotechnology, 26 (11): 631-638. doi: 10.1016/j.tibtech.2008.07.002

LERCHE W. (1936/1937). Untersuchungen über Entwicklung und Fortpflanzung in der Gattung Dunaliella. Archiv für Protistenkunde, 88: 236-268. (in German)

LeRs A., BIENER Y., ZAMIR A. (1990). Photoinduction of massive $\beta$-carotene accumulation by the alga Dunaliella bardawil kinetics and dependence on gene activation. Plant physiology, 93 (2): 389-395. doi: 10.1104/pp.93.2.389

LOEBLICH L.A. (1982). Photosynthesis and pigments influenced by light intensity and salinity in the halophile Dunaliella salina (Chlorophyta). Journal of the Marine Biological Association of the United Kingdom, 62 (3): 493-508. doi: 10.1017/S0025315400019706

LÓPez E., Aguilera P.A., Schmitz M.F., CASTRo H., PinedA F.D. (2010). Selection of ecological indicators for the conservation, management and monitoring of Mediterranean coastal Salinas. Environmental monitoring and assessment, 166 (1-4): 241-256. doi: 10.1007/s10661-009-0998-2

MARÍN N., MORALES F., LODEIROS C., TAMIGNEAUX E. (1998). Effect of nitrate concentration on growth and pigment synthesis of Dunaliella salina cultivated under low illumination and preadapted to different salinities. Journal of Applied Phycology, 10 (4): 405-411. doi: 10.1023/A:1008017928651

MÄrZ U. (2008). FOD025C-The Global Market for Carotenoids. Wellesley, MA USA: BCC Research, 153 p.

MASSJUK N.P. (1973). Morfologia, sistematika, ekologia, geograficheskoe rasprostranenie roda Dunaliella Teod. i perspektivy ego prakticheskogo ispolzovania. Kiev: Naukova Dumka, 244 p. (in Russian)

MENDOZA H., JimÉNEZ DEl Río M., GARCÍA R.G., RAMAZANOv Z. (1996). Low-temperature-induced $\beta$-carotene and fatty acid synthesis, and ultrastructural reorganization of the chloroplast in Dunaliella salina (Chlorophyta). European Journal of Phycology, 31 (4): 329-331. doi: 10.1080/09670269600651551

MiL'KO S.I., KOMARISTAYA V.P., RUDAS A.N. (2011). Effect size of some factors influencing productivity indexes in Dunaliella salina Teod. culture. Karazinski Pryrodnychi Studii. Mat. mezhdunar. nauch. konf. Ukraine, Kharkiv: V.N. Karazin Kharkov National University, February 1-4, 2011: 293-295.

OREN A. (2009). Saltern evaporation ponds as model systems for the study of primary production processes under hypersaline conditions. Aquatic Microbial Ecology, 56 (2-3): 193-204. doi: 10.3354/ame01297 
OREN A. (2014). The ecology of Dunaliella in high-salt environments. Journal of Biological ResearchThessaloniki, 21 (1): 23-40. doi: 10.1186/s40709-014-0023-y

Rabbani S., Beyer P., Lintig J., Hugueney P., Kleinig H. (1998). Induced $\beta$-carotene synthesis driven by triacylglycerol deposition in the unicellular alga Dunaliella bardawil. Plant Physiol, 116 (4): 12391248. doi: 10.1104/pp.116.4.1239

Ramos A., Coesel S., Marques A., Rodrigues M., Baumgartner A., Noronha J., Rauter A., Brenig B., VARELA J. (2008). Isolation and characterization of a stress-inducible Dunaliella salina Lcy- $\beta$ gene encoding a functional lycopene $\beta$-cyclase. Applied microbiology and biotechnology, 79 (5): 819828. doi: 10.1007/s00253-008-1492-4

Ramos A.A., Marques A.R., Rodrigues M., Henriques N., Baumgartner A., Castilho R., Brenig B., VARELA J.C. (2009). Molecular and functional characterization of a cDNA encoding 4-hydroxy-3methylbut-2-enyl diphosphate reductase from Dunaliella salina. Journal of plant physiology, 166 (9): 968-977. doi: 10.1016/j.jplph.2008.11.008

Rodrigues C.M., Bio A., AMAT F., VIEIRA N. (2011). Artisanal salt production in Aveiro/Portugal - an ecofriendly process. Saline Systems, 7 (3), 14 p. doi: 10.1186/1746-1448-7-3

ROESSLER P.G. (1990). Environmental control of glycerolipid metabolism in microalgae: commercial implications and future research directions. Journal of Phycology, 26 (3): 393-399. doi: 10.1111/j.0022-3646.1990.00393.x

SÁncheZ-Estudillo L., Freile-Pelegrin Y., RiverA-Madrid R., Robledo D., NARVÁEZ-ZaPATA J.A. (2006). Regulation of two photosynthetic pigment-related genes during stress-induced pigment formation in the green alga, Dunaliella salina. Biotechnology letters, 28 (11): 787-791. doi: 10.1007/s10529-006-9001-2

SCHLIPALIUS L. (1991). The extensive commercial cultivation of Dunaliella salina. Bioresource technology, 38 (2): 241-243. doi: 10.1016/0960-8524(91)90162-D

Shaish A., AVRon M., Pick U., Ben-Amotz A. (1993). Are active oxygen species involved in induction of $\beta$ carotene in Dunaliella bardawil? Planta, 190 (3): 363-368. doi: 10.1007/BF00196965

WOLF Y.I., KAREV G., KoONIN E.V. (2002). Scale-free networks in biology: new insights into the fundamentals of evolution? Bioassays, 24 (2): 105-109. doi: 10.1002/bies.10059

Рекомендує до друку

Надійшла 05.01.2018

Костіков І.Ю.

Aдреси авторів:

В.П. Комариста, К.М. Білоусова

Харківський національний університет

ім. В.Н. Каразіна

Майд. Свободи, 4

Харків 61022

e-mail: v.p.komarysta@karazin.ua

O.M. Рудась

ТОВ Бетакар-XР

б. 38, кв. 80, вул. Гвардійціів Широніниів

Харків 61123

e-mail:ecobioton@gmail.com
Author's address:

V.P. Komaristaya, K.M. Bilousova

Kharkiv National University

Svobody $S q, 4$

Kharkiv 61022

Ukraine

e-mail:v.p.komarysta@karazin.ua

Rudas O.M.

TOV Belakar-XP

Gvardiitsiv Shyronintsiv Str., 38, 80

Kharkiv 61123

e-mail:ecobioton@gmail.com 